\title{
Context of Implicit Hegemonic Discourse in Contemporary China
}

\author{
Xinfa Yuan', Jiuquan Han'2 \\ ${ }^{1}$ Foreign Language Department of Baoding University, Baoding, China \\ ${ }^{2}$ College of Foreign Language of Hebei Agricultural University, Baoding, China \\ Email: yuanxinfa66@163.com
}

Received 17 March 2015; accepted 5 April 2015; published 13 April 2015

Copyright (C) 2015 by authors and Scientific Research Publishing Inc.

This work is licensed under the Creative Commons Attribution International License (CC BY). http://creativecommons.org/licenses/by/4.0/

(c) (i) Open Access

\begin{abstract}
Following the principles of rhetorical political approach and discourse-historic approach, this paper discusses the context of how implicit hegemonic discourse(IHD) manipulators in contemporary China discursively justify their own special interests and mislead the dominated to "maintain consent" to the current hegemony pernicious to the future of Chinese civilization. This context involves IHD manipulators' subjective and partial interpretation on their lingui-philosophical, political and ethical orientations, in which ethical value locates as the core determining the other three elements. Finally, the author puts forward a new trinity to dissolve IHD in contemporary China.
\end{abstract}

\section{Keywords}

Implicit Hegemonic Discourse, Rhetorical Political Approach, Discourse-Historic Approach, Context, Dissolution, Contemporary China

\section{Introduction}

In contemporary China, most Chinese used to be dominated by five volumes of Mao Zedong's Selected Works from the 1960s to the late 1970s, which was greatly reversed by discourses of introspection, liberation of thoughts, reformation and opening to the outside world in the 1980s. Since the 1990s, special interest groups came into being and the term in Chinese as Teshu Liyi Jituan was first put forth politi-economically by Zhou (2009: pp. 18-19), a famous editorial writer in Jiefang Daily pen-named as Huangpu Ping. He argues that the coalition of mighty capital elites from some state-owned enterprises, gigantic privately-run corporations and mighty political elites is conducive for the special interest groups to hold sway over the national policy, swallow national asset and possess and squander the public resources, which brings forth two socio-political risks. First, 
the special interest groups not only swallow most of natural resources but also bribe some experts to create discursive power to defense their interest. Second, the special groups manage to find their spokesman at various levels of governments. From then on, the term came to be widely used in various media. Recently, Zhou reiterates this topic in Nanfang Daily (Duan \& Zhou, 2012) that the chief task of a thorough reformation of market economy in China is to eradicate corporate consolidation, expansion and domination upon Chinese politics, economics and culture.

Under the discursive setting, the author, with rhetorical political analysis (RPA) and discourse-historical approach (DHA), will discuss the context of how IHD manipulators discursively justify their own special interests, and mislead the dominated to "maintain consent" with the present hegemony. And the author find that the IHD context involves manipulators' subjective and partial interpretation on their communicative objectives and lingui-philosophical, political and ethical orientations, in which ethical orientation locates as the core determining the other elements.

\section{Context for Implicit Hegemonic Discourse Production}

According to Van Dijk (2007: p. 295), the interaction between social structures and discourse structures is mediated by socio-psychological context

... if participants also keep an ongoing, subjective interpretation of themselves, other participants, and their properties and relations, and other relevant aspects of the communicative event as represented in some kind of mental model. These context models define what participants find or make relevant for their ongoing contribution (Van Dijk, 2007: p. 295).

And this interpretation is restrained by

The subjectivity of context: Contexts are not objectively out there, but the result of personal, subjective understandings of the communicative situation. That is, contexts are personal constructs.

The partiality of context: The subjective, constructed nature of mental models allows that contexts are partial, and "ignore" large parts of the social situation. Thus, by constructing context models, participants ongoingly and flexibly select what is now relevant for them (Van Dijk, 2007: pp. 290-291).

Wodak \& Meyer (2009) develop this argument by stating that it is not objective social situations (determined by social structures) that influence language variation but rather it is the "subjective definitions of the relevant properties of these communicative situations that influence talk and text,” (Wodak \& Meyer, 2009: p. 14).

Following the theories above, the author will discuss the subjectivity and partiality of IHD context reflected in the manipulators' lingui-philosophical, political and ethical orientations contributing to a mutualistic symbiosis, in which the ethical orientation determines the other two-lingui-philosophical and political orientations, and conversely, they support and protect the core from outer interference (See Figure 1).

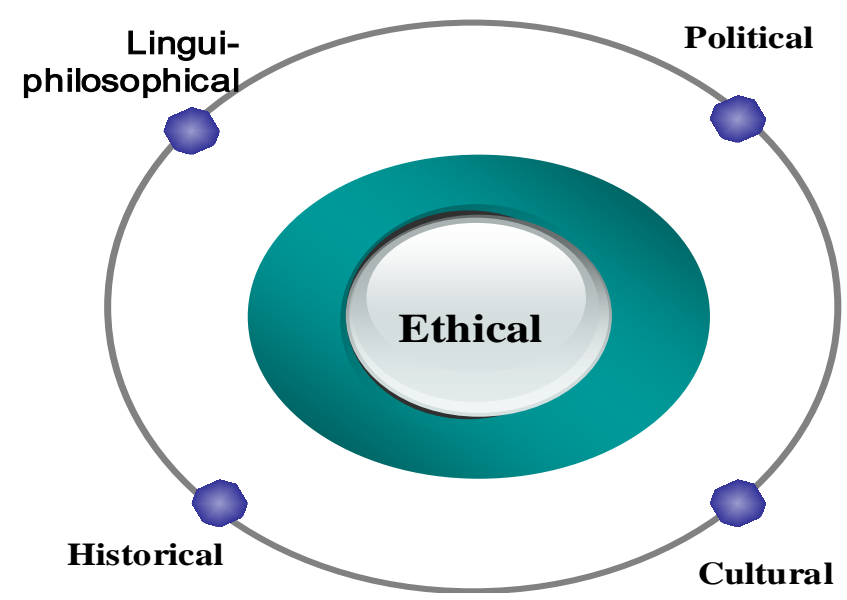

Figure 1. The mutualistic symbiosis. 
Furthermore, the author will have a deeper analysis into the IHD makers' ethical orientation by focusing on the historical intertextuality of demoralization between ancient and contemporary discourses.

\subsection{Lingui-Philosophical Orientation}

Lingui-philosophically, the IHD manipulators directly or indirectly practice functionalism or extreme individualism. Functionalism, according to Shi (2006: p. 134), is an important basis for European philosophy of language. It holds that language is a tool for human beings to fulfill themselves. In a deeper and broader cultural-ethical sense, functionalism derives from instrumental rationalism and extreme individualism which argue for self-fulfillment rather than social harmony. Such a lingui-philosophical thinking runs counter to the doctrine of Chinese philosophy of language that a discursive activity is to build harmony between man and nature, to establish morality based on righteousness, benevolence and propriety.

\subsection{Political Orientation}

In line with their lingui-philosophical thinking, the IHD manipulators erect a political power value system serving their own interests. According to Weber (2006: p. 81), there are two types of political power operations: positive and negative. Namely, the authority operates power either morally and legally to have a harmonious society, or rather, immorally, though sometimes legally, to maximize their own benefits, and only to exacerbate social conflicts and result in social instability and even dramatic collapse because public rights have been deprived of by those special interests' groups.

Driven by the negative interpretation of political power, some large state-owned enterprises in contemporary China have become the sign of monopoly; a large number of private businessmen manage to bribe some officials who often hold an umbrella for the businessmen's illegal or inhumane behaviors. Furthermore, some "professors", "experts", enticed by the illegal or immoral income, indulge themselves in making theoretical excuses for those corrupted officials and immoral businessmen. In this way, an iron triangle has been constructed based on their shared interests. Their unification directly leads to the monopoly of administration and economy, to the malformation of political power system.

\subsection{Ethical Orientation}

In the world of human beings, two main streams of ethical values, Kantian and Machiavellian, dominate man's modes of thinking and action.

Most people uphold the doctrine of equality, the universal law dealing with personal free will and social harmony. Confucius: "Do not impose on others what you do not want." (Analects of Confucius, Chapter 12) Jesus Christ: "And as ye would that men should do to you, do ye also to them ..." (Luke 6:31) Mohammad: Woe to the cheaters who demand full measure when receiving from the people but when giving them the measures or weights, they cheat. (Alcoran, Sura 83) Sakyamuni: Put your own foot into other's shoes, then you will do no harm to him/her (The Dharmapada, Chapter 6).

Kant's (1993: p. 30) categorical imperative deals with the same issue from the other side. According to Kant (1993), there are two types of imperatives: categorical and hypothetical. The former denotes an absolute, unconditional requirement that asserts its authority in all circumstances, both required and justified as an end in itself (Kant, 1993: p. 30). In Singer \& Patten's (2006: p. 112) words, Kant's categorical imperative can be artistically represented by the word "LOVE" maximizing freedom, justice and equality. Hypothetical imperatives, on the contrary, compel actions in given circumstance. Namely, they rely too heavily on subjective considerations.

In fact, when hypothetical imperatives are taken to the extreme degree, they will develop into Machiavellism, which is defined as "a process by which the manipulator gets more of some kind of reward than he would have gotten without manipulating, while someone else gets less, at least within the immediate context" (Christie \& Geis, 1970: p. 106).

A Machiavellian is cold-blooded and conniving in using others with total disregard for human dignity. The Machiavelli (Mach) scale measures an individual's willingness to put self-interest and his or her preferences above the interests of the group, and an individual's ability to influence and manipulate others for personal gain. (Jaffe et al., 1989) Individuals with a high score on the scale are comfortable using various means to achieve their personal goals (Rayburn \& Rayburn, 1996). People who were high in Machiavellism used indirect, non- 
rational tactics like deceit, but also appealed to emotions to try to plant their ideas to influence their colleagues (Grams \& Rogers, 1990).

Those IHD manipulators just, consciously or unconsciously, take a Machiavellian way by holding a selforiented lingui-philosophical thinking mode and construct a self-centered power value.

There might be various reasons for the IHD manipulators in contemporary China to hold this ethical orientation. Genetically, human beings are born selfish (Dawkins, 1976: p. 3) and greedy and they would keep it to death unless socially educated, let alone IHD manipulators. But this genetic interpretation is far from sufficient. The long historical demoralization blooming in the intertextuality between ancient and contemporary Chinese discourses is the essential yeast for solid aggregation and dilation of their selfish ethic.

The long historical demoralization heritage could be traced back from several centuries BC to the 1980s and 1990s. Although the age of 1980s-1990s is quite different from that of independent warlords scrambling for supremacy two thousand years ago, they share the same feature that enriching and strengthening one's own state were in a desperate need for powerful talents regardless of their moral values. Sometimes, they might even quench a thirst with poison by only stressing sheer capability of capturing territories in the ancient time or making a lot of money at the contemporary age.

One controversial historical figure named Wu Qi (440BC.-381BC.), a general in the period of Warring States (475BC.-221BC.), for instance, was often historic-discursively compared with Sun Bin (379BC.-314BC.) - one of the most important strategists in ancient Chinese history. In his masterpiece of The Record of History, Sima Qian (2004), one of the most famous historian in the West Han Dynasty (206 BC-24 AD), had a vivid historical description, in which there were quite few direct or indirect criticism on the wickedness of Wu Qi. Namely, except for a rather direct and short ambiguous introduction of Wu's killing his wife to pursue his personal fame, all other comments were quoted from others in the State of Lu who condemned $\mathrm{Wu}$ as a dubious and merciless, greedy and lustful man because of his refusal to go home to bury his mother.

On the contrary, Sima Qian devoted most of his attention to extol Wu's military achievements such as conquering the State of Qi when serving as a general in the State of Lu, seizing five cities from the State of Qin when serving in the State of Wei, reforming the legal system and defeating all the enemies around the State of Chu when serving as a prime minister. Furthermore, Sima had a great sympathy for Wu's behavior by describing some people as “those saying bad words against Wu”, or as those jealous of Wu's capability.

The ghost of Wu Qi haunted Chinese later historic periods when everything needed to be done. One of the most typical example was highlighted by Cao Cao's three Decrees of Pursuing Talents during the period of Three Kingdoms (220AD.-280AD.), which set up the banner of “Capacity is the first and foremost” in employing officials at various levels while totally regardless of their moral standards. In the 1980s-1990s, this ghost haunted China that was extremely thirsty for knowledge and talents after having walked out of the Great Cultural Revolution. As a result, ambitious people in the prime of their enterprising life came to the historic proscenium while those with their high personal ethics and integrity faded out of public sight. More and more people, led by those editorials and essays in People's Daily, confined "knowledge" to "expertise” in the 1980s and “ability to make money” in the 1990s.

In the mid 1980s, to be more specific, the People's Daily launched a milestone discussion on new ideals of talents. Its editorial entitled “Be brave to select and employ those who dare be innovative” (Page 1, 1984/09/14) established epochal standards for new talents: 1) Adhering to Marx-Leninism; 2) Being young with new knowledge, new technology, new ideas and new experience; 3) Being intensely ambitious, responsible and far-sighted; 4) Being able to follow the true and good. At the end of this editorial, interestingly, the author did not forget to mention that people should be tolerant of those talents' various defects.

Within only five months (from February to June, 1985) following this pioneering editorial, more than ten essays were published successively, earnestly and most imperatively in the People's Daily: Don't be too “demanding” on prodigies (Page 8, 1985/2/7), Too perfect to be true (Page 8, 1985/2/13), Invigorate the way of selecting the talents (Page 1, 1985/2/16), An essay of spring (Page 4, 1985/2/22), Unnecessary in selecting a cadre on better votes (Page 8, 1985/3/21), No set form for selecting a talent (Page 3, 1985/2/13), Times changes (Page 8, 1985/3/25), Select both young and old talents (Page 8, 1985/2/13), Say goodbye to the past and welcome the new year (Page 8, 1985/3/17), Be bold to employ talents with errors (Page 8, 1985/3/19), Reform and open policy calling for rapid growth of talents (Page 8, 1985/4/9) Fearless of gossips in selecting a talent (Page 3, 1985/5/19).

These imperative essays steered the whole nation to a new but wrong direction since they criticized the old 
principle laying too strong demand on one's personal ethics and integrity and too little on one's capability of reformation. At the same time, they prayed for new standards of hiring a capable person even though he is found to be somewhat morally imperfect or they have committed certain errors.

The new editorial titled "Don't be obstructed in selecting a cadre" (Page 2, 1985/6/9) in the People's Daily made a fine yet historic tuning, in which "being in one's prime of life" ranked the first, followed by "being somewhat knowledgeable”, "having moral integrity” and " being innovative.” This discursive change indicated that the first and foremost principle of selecting a cadre — ethic integrity — has retreated to the third position.

In the 1990s, this poisonous thirst quenching of selecting a cadre underwent a socio-economical-and-political metamorphosis from "Capability comes first, moral second" to "Capability of making money is everything", which was represented by the abuse of a famous slogan "Time is life, and time is money" in Shenzhen from 1980s to 1990s. This totally went against Chinese traditional officialdom philosophy—-those in lack of moral integrity cannot be an official.

This historic choice was doomed to facilitate immoral officials' mushrooming within approximately ten years. They begin to be in solid collusion with each other and permeate into every field of the whole society. At the 21st Century, success and money instead of integrity are so frequently prominent on various media that success for wealth, in most Chinese eyes, is the ultimate meaning irrespective of the means he may take.

To sum it up, the Machiavellian prominence now and then in most Chinese history gives rise to IHD manipulators’ distorted ethical, lingui-philosophical and political interpretations of life style.

\section{Conclusion and Implication}

Based on the principles of rhetorical political approach and discourse-historic approach, this paper discusses the context of how implicit hegemonic discourse(IHD) manipulators in contemporary China justify their own special interests and mislead the dominated to "maintain consent" to the current hegemony pernicious to the future of Chinese civilization. This context involves IHD manipulators' subjective and partial interpretation on their lingui-philosophical, political and ethical orientations, in which ethical value locates as the core determining the other elements.

Following the description of IHD's performances and contextual interpretation, the author offers a few suggestions to dissolve the sharp aggregation and extension of IHD in contemporary China:

First, a fair ethic-cultural climate should be created so that more and more just undertakers have the opportunity to govern the society under the principle of dignity, equality and harmony.

Second, the core of choosing an official should take a substantive shift from "Capability first" to "Morality first" because he/she is discursively and behaviorally more charismatic for others to follow suit.

Third, the disadvantaged groups' voice should be well-protected and strengthened. According to the Department of Editorial, People's Daily (2011), "It's the duty for various levels of governments to guarantee the vulnerable groups' rights to be informed, to participate, to be heard so that their reasonable benefits can be ensured normally and systematically." "To hear and to be heard are the basic appeal for a 'social being'; speaking and listening to others is the consensus of modern civilization."

In brief, a new trinity of fair ethic culture, socio-political systems advocating equality, dignity and benevolence (See Figure 2) is highly necessary to slow the steps of IHD’s wild growth, and eventually, dissolve it.

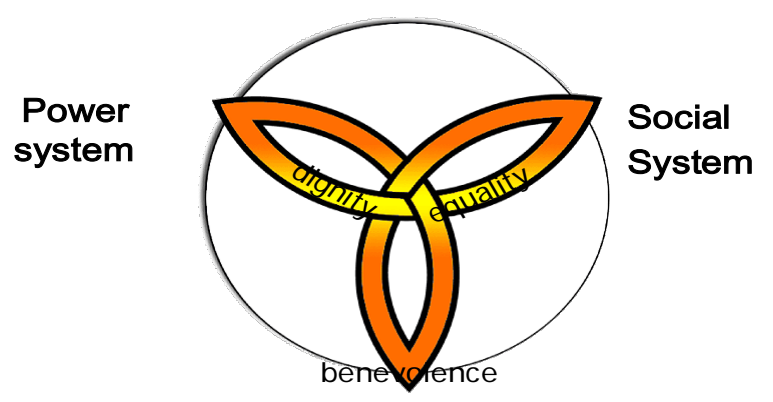

Ethic Culture 


\section{References}

Christie, R., \& Geis, F. (1970). Studies in Machiavellianism. New York: Academic Press.

Dawkins, R. (1976). The Selfish Gene (p. 3). New York City: Oxford University Press.

Department of Editorial (2011). Listening to Those "Sunken Voice”. People's Daily, 14.

Duan, G. W., \& Zhou, H. C. (2012). Zhou’s Review of Deng Xiaoping’s Comments in Shenzhen, 1991: Reformation Should Become the Mainstream Value of the CCP. Nanfang Daily, A05.

Grams, W., \& Rogers, R. (1990). Power and Personality: Effects of Machiavellianism, Need for Approval, and Motivation on Use of Influence Tactics. Journal of General Psychology, 117, 71-82. http://dx.doi.org/10.1080/00221309.1990.9917774

Jaffe, E., Nebenzahl, I., \& Gotesdyner, H. (1989). Machiavellianism, Task Orientation, and Team Effectiveness Revisited. Psychological Reports, 64, 819-824. http://dx.doi.org/10.2466/pr0.1989.64.3.819

Kant, I. (1993). Grounding for the Metaphysics of Morals (3rd ed., p. 30). Indianapolis: Hackett Pub. Co.

Rayburn, M., \& Rayburn, L. (1996). Relationship between Machiavellianism and Type A Personality and Ethical Orientation. Journal of Business Ethics, 15, 1209-1219. http://dx.doi.org/10.1007/BF00412819

Shi, X. (2006). Towards a Cultural Turn in Discourse Analysis: Reasons, Objectives and Strategies for Constructing a Chinese Discourse Studies Paradigm. Journal of Zhejiang University (Humanities and Social Sciences), 38, 135-138.

Sima, Q. (2004). Record of History. Changsha: Yuelu Publishing House.

Singer, M., \& Patten, P. (2006). Guidelines for Communication: The Right Tool for Preparing Great Speeches (p. 112). North Muskegon, MI: Punim.

Van Dijk, T. A. (2007). Comments on Context and Conversation. In N. Fairclough, G. Cortese, \& P. Ardizzone (Eds.), Discourse and Contemporary Social Change (pp. 290-295). Bern: Peter Lang.

Weber, M. (2006). Economy and Society (I) (Tr. into Chinese by Lin Yuanrong, p. 81). Beijing: The Commercial Press.

Wodak, R., \& Meyer, M. (2009). Critical Discourse Analysis: History, Agenda, Theory, and Methodology. In R. Wodak, \& M. Meyer (Eds.), Methods for Critical Discourse Analysis (pp. 1, 33). London: Sage.

Zhou, R. J. (2009). Incising the Connection with “Special Interest Groups”. Manager, 23, 18-19. 